\title{
Study of the predictive role of central venous oxygen saturation in acute type I respiratory failure patients
}

\author{
Hesham G. A. Ismail ${ }^{1}$, Hamdy A. Mohammadien², Mohsen M. El-Shafay ${ }^{3}$, Mona T. Hussein \\ 1. Teaching Assistant of Pulmonology, Faculty Of Medicine, Sohag University. \\ 2. Professor of Pulmonology, Faculty Of Medicine, Sohag University. \\ 3. Professor of Pulmonology, Faculty Of Medicine, El-Mansoura University. \\ 4. Assistant Professor of Pulmonology, Faculty Of Medicine, Sohag University.
}

\begin{abstract}
Background: Central venous oxygen saturation ( $\mathrm{ScvO} 2)$ measurement is a safe and efficient alternative for mixed venous oxygen satu ration $(\mathrm{SvO} 2)$ as an indirect estimate for global tissue oxygenation. The normal range of $\mathrm{SvO} 2$, which reflects the balance between $\mathrm{O} 2$ delivery and demands, is 65 to $75 \%$
\end{abstract}

Objectives: This study was designed to determine the predictive role of central venous oxygen saturation $(\mathrm{ScvO} 2)$ in acute type I respiratory failure patients admitted to the pulmonary critical care unit.

Patients and Methods: The study included patients with acute type I respiratory failure patients admitted to the pulmonary critical care unit, Mansoura University Hospitals during the period between August 2015 to December 2015.Central venous blood was withdrawn through a central venous catheter placed via a subclavian approach and advanced to the right atrium as confirmed by post insertion chest x-ray. Samples for $\mathrm{ScvO} 2$ were taken on admission and at the $3^{\text {rd }}$ and $7^{\text {th }}$ day.

Results: 62 patients (51.6\% males) were included with a mean age of 60 years old.Low ScvO2 on admission was associated with increased risk of mortality as did persistent low ScvO2 values on $3^{\text {rd }}$ and $7^{\text {th }}$ day ( $\mathrm{P}$ value $0.001,0.001$ and 0.03 respectively). We calculated cutoff points for $\mathrm{ScvO} 2$ for predicting mortality on admission and at the $3^{\text {rd }}$ and $7^{\text {th }}$ day to be $65 \%$, $70 \%$ and $66 \%$ respectively ( $\mathrm{P}$ value $0.0008,0.04$ and 0.04 respectively).

Conclusion:This study showed that $\mathrm{ScvO} 2$ has a role in predicting mortality in critical care patients presented with acute type I respiratory failure patients and improving $\mathrm{ScvO} 2$ is associated with improving the outcome in such patients, thus justifying the need for a comprehensive and integrating therapeutic approach.

Key Words:ScvO2, SvO2, respiratory failure.

Abbreviations:

ScvO2: Central venous oxygen saturation, SvO2: Mixed venous oxygen saturation, PEEP: Positive end expiratory pressure, ICU: Intensive care unit, PCCU: Pulmonary critical care unit, HTN: Hypertension, DM: Diabetes mellitus, CXR: Chest X-ray, BMI: Body mass index, ILD: Interstitial lung disease, ARDS: Adult respiratory distress syndrome, APACHE: Acute physiology and chronic health evaluation, CVP: Central venous pressure

\section{Introduction}

Measurement of venous oxygen saturation is an indirect way to determine global oxygenation. Venous oxygen saturation is an indirect index of global oxygen supply-todemand ratio (1).Central venous oxygen saturation $(\mathrm{ScvO} 2)$ is the oxygen saturation of central venous blood. This value is obtained by placing a fiber-optic central venous catheter into the superior vena cava. $\mathrm{ScvO} 2$ reflects oxygen saturation of blood returning from the upper body and indicates the balance between oxygen delivery and oxygen consumption in the cranial portion of the body, including the brain (2). Mixed venous oxygen saturation $(\mathrm{SvO} 2)$, on the other hand, is obtained from a pulmonary artery catheter and reflects overall $\mathrm{SvO} 2$ of blood returning from the upper body, the lower body, and the heart via the coronary sinus. Variations in regional blood flow from the upper body, lower body, and heart will affect the absolute values for $\mathrm{ScvO} 2$ and $\mathrm{SvO} 2(2)$. Measurement of mixed venous oxygen saturation $(\mathrm{SvO} 2)$ from the pulmonary artery has been advocated as an indirect index of tissue oxygenation (3). However, use of the pulmonary artery catheter has become somewhat unpopular $(4,5)$. In contrast, insertion of a central venous catheter in the superior vena cava via the jugular or the subclavian vein is considered standard care in critically ill patients. Just like $\mathrm{SvO} 2$, the measurement of central venous oxygen saturation $(\mathrm{ScvO} 2)$ has been advocated in order to detect global tissue hypoxia (6). The first sign that a patient is beginning to decompensate will be a decrease in ScvO2, prior to other 
hemodynamic or lab values changing. This early detection makes continuous $\mathrm{ScvO} 2$ an invaluable tool in the monitoring and treatment of the critically ill patient $(7,8) . \mathrm{SvO} 2$ has been shown to have diagnostic, prognostic, and therapeutic use in the treatment of critically ill patients in the medical ICU and in septic shock. It has also been used in mechanically ventilated patients to determine the optimal level of positive end-expiratory pressure (PEEP) and to assist in weaning from mechanical ventilation $(9,10)$.

\section{Patients and methods}

Clinical trial in which central venous oxygenation will be adopted as an index for tissue oxygenation in acute type I respiratory failure patients. The mortality will be considered as a primary end point. At the end, two groups will be present, dead and survived, each one will be control for the other. Acceptance of Ethical Committeewas gotten. This study was carried out on patients admitted to the pulmonary critical care unit (PCCU), chest department, Mansoura university hospitals during the period between August 2015 to December 2015.

\section{Patients Inclusion criteria}

All acute type I respiratory failure patients admitted to pulmonary critical care unit (PCCU), chest department, Mansoura university hospital.

\section{Patients Exclusion criteria}

- Patients died before 72 hours from admission (before the $2^{\text {nd }}$ sample).

- Patients who admitted to PCCU after cardiopulmonary arrest outside the PCCU.

- Patients with advanced pulmonary fibrosis.

- Patients already diagnosed as lung cancer.

- Patients under cancer chemotherapy.

\section{Methods}

All patients were subjected to the following:

1.Through clinical history.

2 .Through clinical examination:

3. Chest radiographs:

- Chest X-Rays.

- Chest C.T. scan if needed.

- CT pulmonary angiography if needed.

- Chest ultrasound if needed.

4. ECG and echocardiography if needed.

5. Laboratory investigations:

- Complete blood count including differential count.
- Complete metabolic profile (serum urea, serum creatinine, liver enzymes, serum albumin, serum total proteins, serum bilirubin, serum alkaline phosphatase, serum glucose, serum electrolytes (NA+, $\mathrm{K}+, \mathrm{Ca}++$ ).

- Sputum sample for bacterial culture and antibiotic sensitivity was taken from non-intubated patients and by sterile suction through the endotracheal tube in mechanically ventilated patients.

- Nasopharyngeal swab for serological detection of Influenza A H1N1 virus in suspected cases.

- $\quad$ Arterial blood gases.

6.Central venous catheter was inserted through a subclavian approach proceeded into the right atrium which was documented by post insertion CXR "the tip of the catheter being just at the lower border of the right $3^{\text {rd }}$ anterior rib at the right medial border of the sternum".

- Post-insertion portable CXR was taken as a guidance for repositioning of the catheter and for detection of postinsertion pneumothorax.

- Central venous blood sample for central venous $\mathrm{O} 2$ saturation $(\mathrm{ScvO} 2)$ will be taken on PCCU admission, $3^{\text {rd }}$ day and $7^{\text {th }}$ day after withdrawal of $20 \mathrm{ml}$ blood to avoid the effect of frequent catheter flushing. Re-injection of withdrawed blood after sampling.

6. APACHE II scoring was adopted as a severity scoring on admission.

Statistical methods used for data analysis

Data were analyzed using STATA intercooled version 12.1. Quantitative data were represented as mean, standard deviation, median and range. We used student T-test when comparing the mean of survived versus dead groups. In nonparametric data Mann-Whitney test was used. Qualitative data were presented as number and percentage and compared using either Chi square test or fisher exact test. Receiver operating characteristic (ROC) curve was used to determine sensitivity, specificity, positive, and negative predictive value for different $\mathrm{ScvO} 2$ readings. The diagnostic accuracy of different variables was expressed as the area under the ROC curve (AUC). Graphs were produced by using Excel and/or STATA program. P value was considered significant if it was less than 0.05 . 
SOHAG MEDICAL JOURNAL Study of the predictive role of central venous oxygen saturation in acute

\section{Results}

The study was conducted on patients admitted to the Pulmonary Critical Care Unit (PCCU), Mansoura University Hospitals with acute type I respiratory failure during the period between August 2015 and December 2015. After application of inclusion and exclusion criteria, 62 cases were included in this study.

Table (1): Comparison between outcome and demographic data of studied patients

\begin{tabular}{|c|c|c|c|}
\hline Variable & $\begin{array}{c}\text { Survived } \\
\mathbf{n}=17\end{array}$ & $\begin{array}{l}\text { Dead } \\
n=45\end{array}$ & $P$ value \\
\hline $\begin{array}{l}\text { Age/years } \\
\text { Mean } \pm \text { SD } \\
\text { Median (range) }\end{array}$ & $\begin{array}{c}53.47 \pm 16.41 \\
60(27-80)\end{array}$ & $\begin{array}{c}62.49 \pm 17.34 \\
63(17-90)\end{array}$ & 0.07 \\
\hline $\begin{array}{l}\text { Gender } \\
\text { Females } \\
\text { Males }\end{array}$ & $\begin{array}{c}12(70.59 \%) \\
5(29.41 \%)\end{array}$ & $\begin{array}{l}18(40.00 \%) \\
27(60.00 \%)\end{array}$ & 0.03 \\
\hline \begin{tabular}{lc}
\multicolumn{2}{l}{ Smoking status } \\
Non-smoker & $\mathrm{n}=\mathbf{4 2}$ \\
Smoker & $\mathrm{n}=10$ \\
Ex-smoker & $\mathrm{n}=10$
\end{tabular} & $\begin{array}{c}15(88.24 \%) \\
2(11.76 \%) \\
0\end{array}$ & $\begin{array}{c}27(60.00 \%) \\
8(17.78 \%) \\
10(22.22 \%)\end{array}$ & 0.06 \\
\hline $\begin{array}{l}\text { BMI } \\
\text { Mean } \pm \text { SD } \\
\text { Median (range) }\end{array}$ & $\begin{array}{c}23.36 \pm 1.15 \\
24.8(21.53-25.85)\end{array}$ & $\begin{array}{c}24.42 \pm 1.47 \\
24.77(20.91-27.21)\end{array}$ & 0.87 \\
\hline
\end{tabular}

\section{BMI: Body Mass Index}

17 cases (27\%) survived while 45 cases (73\%) died.The mean age among living was 53 years (range 27-80) while in the mortality group was 62 years (range 17-90). The mean body mass index "BMI" among living was 23 (range 22-26) respectively while that in the mortality groupwas 24 (range 21-27).Mortality was high in non-smokers (60\%) than ex-smokers (22\%) and current smokers (18\%).

Table (2): Comparison between outcome and diagnosis

\begin{tabular}{|c|c|c|c|}
\hline Diagnosis & $\begin{array}{c}\text { Survived } \\
\mathrm{n}=17\end{array}$ & $\begin{array}{c}\text { Mortality } \\
n=45\end{array}$ & $P$ value \\
\hline 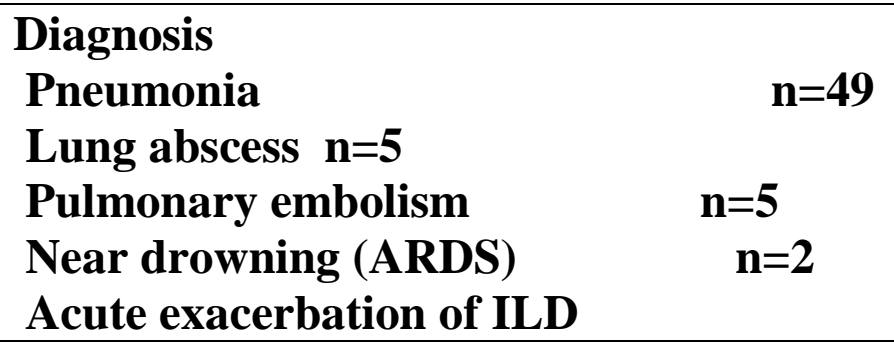 & $\begin{array}{c}13(76.47 \%) \\
1(5.88 \%) \\
3(17.65 \%) \\
0 \\
0 \\
\end{array}$ & $\begin{aligned} & 36(80.00 \%) \\
& 4(8.89 \%) \\
& 2(4.44 \%) \\
& 2(4.44 \%) \\
& 1(2.22 \%) \\
&\end{aligned}$ & 0.63 \\
\hline ARDS & $\mathbf{0}$ & $17(37.78 \%)$ & 0.006 \\
\hline $\begin{array}{l}\text { Bacterial infection } \\
\text { No } \\
\text { Yes }\end{array}$ & $\begin{array}{c}3(17.65 \%) \\
14(82.35 \%)\end{array}$ & $\begin{array}{c}2(4.44 \%) \\
43(95.56 \%)\end{array}$ & 0.12 \\
\hline $\begin{array}{l}\text { Influenza A H1N1 infection } \\
\text { No } \\
\text { Yes }\end{array}$ & $\begin{array}{c}15(88.24 \%) \\
2(11.76 \%)\end{array}$ & $\begin{array}{c}42(93.33 \%) \\
3(6.67 \%)\end{array}$ & 0.61 \\
\hline
\end{tabular}

ARDS: Acute respiratory Distress Syndrome

\section{ILD: Interstitial Lung Disease}

36 cases with poor outcome $(80 \%)$ had pneumonia, There was a high significant relation between development of ARDS and poor outcome (P value 0.006).

Table (3): Comparison between central venous oxygen saturation and outcome

\begin{tabular}{|c|c|c|c|}
\hline Variable & $\begin{array}{c}\text { Survived } \\
\mathrm{n}=17\end{array}$ & $\begin{array}{c}\text { Mortality } \\
\mathrm{n}=45\end{array}$ & P value \\
\hline $\begin{array}{l}\text { ScvO2 day 0 } \\
\text { Mean } \pm \text { SD } \\
\text { Median (range) }\end{array}$ & $\begin{array}{l}71.94 \pm 2.84 \\
72(66-76)\end{array}$ & $\begin{array}{c}66.09 \pm 8.80 \\
66(49-80)\end{array}$ & 0.009 \\
\hline $\begin{array}{l}\text { ScvO2 day } 3 \\
\text { Mean } \pm \text { SD } \\
\text { Median (range) }\end{array}$ & $\begin{array}{c}70.18 \pm 7.95 \\
72(52-84)\end{array}$ & $\begin{array}{c}64.42 \pm 11.54 \\
65(26-83)\end{array}$ & 0.04 \\
\hline $\begin{array}{l}\text { ScvO2 day } 7 \\
\text { Mean } \pm \text { SD } \\
\text { Median (range) }\end{array}$ & $\begin{array}{c}73.76 \pm 2.61 \\
74(68-77)\end{array}$ & $\begin{array}{c}65.37 \pm 11.20 \\
66(35-79)\end{array}$ & 0.005 \\
\hline
\end{tabular}

Scv02: central venous oxygen saturation 
SOHAG MEDICAL JOURNAL Study of the predictive role of central venous oxygen saturation in acute

The mean $\mathrm{ScvO} 2$ on admission in survived patients was $72 \%$ while in dead patients it was $66 \%$. At day 3, the mean $\mathrm{ScvO} 2$ in survived patients was $70 \%$ while in dead patients it was $64 \%$. At day 7, the mean $\mathrm{ScvO} 2$ in survived patients was $74 \%$ while in dead patients it was $65 \%$. There was a significant relation between $\mathrm{ScvO} 2$ values on admission and at the $3^{\text {rd }}$ and $7^{\text {th }}$ day and mortality ( $\mathrm{P}$ value $0.009,0.04$ and 0.005 respectively).

Table (4): Comparison of $\mathrm{ScvO} 2$ at day 0 between survived patients and mortality group

\begin{tabular}{|c|c|c|c|c|}
\hline ScvO2 at day 0 & No & $\begin{array}{c}\text { Survived } \\
\mathrm{n}=17\end{array}$ & $\begin{array}{c}\text { Mortality } \\
n=45\end{array}$ & P value \\
\hline Normal $(65 \%-75 \%)$ & 34 & $16(94.12 \%)$ & $18(40.00 \%)$ & \multirow[t]{2}{*}{$<0.0001$} \\
\hline Abnormal $(<65 \%$ and $>75 \%)$ & 28 & $1(5.88 \%)$ & $27(60.00 \%)$ & \\
\hline Low $(<65 \%)$ & 19 & $\mathbf{0}$ & $19(42.22 \%)$ & 0.001 \\
\hline High $(>75 \%)$ & 9 & $1(5.88 \%)$ & $8(17.78 \%)$ & 0.42 \\
\hline
\end{tabular}

ScvO2: central venous oxygen saturation

Abnormal ScvO2 on admission has significant relation to mortality (P value $<0.0001$ ). Low $\mathrm{ScvO} 2$ on admission was significantly related to mortality more than high admission $\mathrm{ScvO} 2(\mathrm{P}$ value 0.001 and 0.42 respectively).

Table (5): Comparison between outcome and ScvO2 at day 3

\begin{tabular}{|c|c|c|c|c|}
\hline ScvO2 at day 3 & No & $\begin{array}{c}\text { Survived } \\
\mathrm{n}=17\end{array}$ & $\begin{array}{c}\text { Mortality } \\
n=45\end{array}$ & P value \\
\hline Normal $(65 \%-75 \%)$ & 32 & $15(88.24 \%)$ & $17(37.78 \%)$ & \multirow[t]{2}{*}{$<0.0001$} \\
\hline Abnormal $(<65 \%$ and $>75 \%)$ & 30 & $2(11.76 \%)$ & $28(62.22 \%)$ & \\
\hline Low $(<65 \%)$ & 20 & $\mathbf{0}$ & $20(44.44 \%)$ & 0.001 \\
\hline High $(>75 \%)$ & 10 & $2(11.76 \%)$ & $8(17.78 \%)$ & 0.71 \\
\hline
\end{tabular}

Scv02: central venous oxygen saturation

Abnormal ScvO2 on day 3 has significant relation to mortality (P value $<0.0001$ ) Low $\mathrm{ScvO} 2$ on day 3 was significantly related to mortality more than high $\mathrm{ScvO} 2$ on day 3 ( $\mathrm{P}$ value 0.001 and 0.71 respectively).

Table (6): Comparison between ScvO2 at day 7 and outcome

\begin{tabular}{|c|c|c|c|c|}
\hline ScvO2 at day 7 & No & $\begin{array}{c}\text { Survived } \\
\mathbf{n}=\mathbf{1 7}\end{array}$ & $\begin{array}{c}\text { Mortality } \\
n=19\end{array}$ & $P$ value \\
\hline Normal $(65 \%-75 \%)$ & 18 & $12(70.59 \%)$ & $6(31.58 \%)$ & \multirow[t]{2}{*}{0.02} \\
\hline Abnormal $(<65 \%$ and $>75 \%)$ & 18 & $5(29.41 \%)$ & $13(68.42 \%)$ & \\
\hline Low $(<65 \%)$ & 8 & $\mathbf{0}$ & $8(42.11 \%)$ & $\mathbf{0 . 0 3}$ \\
\hline High $(>75 \%)$ & 10 & $5(29.41 \%)$ & $5(26.32 \%)$ & 1.00 \\
\hline
\end{tabular}

ScvO2: central venous oxygen saturation

36 patients survived to day 7 . Abnormal $\mathrm{ScvO} 2$ on day 7 has significant relation to mortality (P value 0.02 ). Low $\mathrm{ScvO} 2$ on day 7 was related to mortality more than high $\mathrm{ScvO} 2$ on day 7

$(\mathrm{P}$ value 0.03$)$.

Table (7): Comparison between change in ScvO2 between day 0 and day 3 and outcome

\begin{tabular}{|l|c|c|c|c|}
\hline & No & $\begin{array}{c}\text { Survived } \\
\mathbf{n}=17\end{array}$ & $\begin{array}{c}\text { Mortality } \\
\mathbf{n}=45\end{array}$ & P value \\
\hline $\begin{array}{l}\text { Improvement in ScvO2 } \\
\text { between day 0 and day } \\
3\end{array}$ & 27 & $11(64.71 \%)$ & $16(35.56 \%)$ & 0.009 \\
\hline $\begin{array}{l}\text { Deterioration in ScvO2 } \\
\text { between day 0 and day } \\
3\end{array}$ & 32 & $6(35.29 \%)$ & $26(57.78 \%)$ & \\
\hline No change & 3 & 0 & $3(6.67 \%)$ & \\
\hline
\end{tabular}

ScvO2: central venous oxygen saturation

There was a significant relation between deterioration of $\mathrm{ScvO} 2$ from day 0 to day 3 and mortality ( $\mathrm{P}$ value 0.009 ). 
SOHAG MEDICAL JOURNAL Study of the predictive role of central venous oxygen saturation in acute

Table (8): Comparison between change in ScvO2 between day 3 and day 7 and outcome

\begin{tabular}{|c|c|c|c|c|}
\hline & No & $\begin{array}{c}\text { Survived } \\
\mathbf{n}=17\end{array}$ & $\begin{array}{c}\text { Mortality } \\
n=19\end{array}$ & $P$ value \\
\hline $\begin{array}{l}\text { Improvement in } \mathrm{ScvO2} \\
\text { between day } 3 \text { and day } \\
7\end{array}$ & 18 & $12(70.59 \%)$ & $6(31.58 \%)$ & \multirow[t]{3}{*}{0.006} \\
\hline $\begin{array}{l}\text { Deterioration in } \mathrm{ScvO2} \\
\text { between day } 3 \text { and day } \\
7\end{array}$ & 16 & $3(17.65 \%)$ & $13(68.42 \%)$ & \\
\hline No change & 2 & $2(11.76 \%)$ & $\mathbf{0}$ & \\
\hline
\end{tabular}

ScvO2: central venous oxygen saturation

There was a significant relation between deterioration of $\mathrm{ScvO} 2$ from day 3 to day 7 and mortality (P value 0.006$)$.

Table (9): Comparison between change ScvO2 between day 0 and day 7 and outcome

\begin{tabular}{|l|c|c|c|c|}
\hline & No & $\begin{array}{c}\text { Survived } \\
\mathbf{n}=17\end{array}$ & $\begin{array}{c}\text { Mortality } \\
\mathbf{n}=19\end{array}$ & P value \\
\hline $\begin{array}{l}\text { Improvement in ScvO2 } \\
\text { between day 0 and day } \\
7\end{array}$ & 19 & $11(64.71 \%)$ & $\mathbf{8 ( 4 2 . 1 1 \% )}$ & 0.02 \\
\hline $\begin{array}{l}\text { Deterioration in ScvO2 } \\
\text { between day 0 and day } \\
7\end{array}$ & 14 & $3(17.65 \%)$ & $11(57.89 \%)$ & \\
\hline No change & 3 & $3(17.65 \%)$ & & \\
\hline
\end{tabular}

ScvO2: central venous oxygen saturation

There was a significant relation between deterioration of $\mathrm{ScvO} 2$ from day 0 to day 7 and mortality (P value 0.02).

Table (10): Diagnostic cut off value, AUC, sensitivity, specificity, and positive and negative predictive values (percentages) of APACHE II score, ScvO2 for predicting mortality in studied population

\begin{tabular}{|c|c|c|c|c|c|c|c|c|}
\hline Variable & Cutoff & $\begin{array}{c}\text { AUC } \\
(95 \% \text { CI })\end{array}$ & $\begin{array}{c}\text { Sensitivity } \\
\%\end{array}$ & $\begin{array}{c}\text { Specificity } \\
\%\end{array}$ & $\begin{array}{c}\text { PPV } \\
\%\end{array}$ & $\begin{array}{c}\text { NPV } \\
\%\end{array}$ & $\begin{array}{c}\text { Accuracy } \\
\%\end{array}$ & P value \\
\hline $\begin{array}{l}\text { APACHE II } \\
\text { score }\end{array}$ & $>27$ & $0.77(0.68: 0.89)$ & 42.22 & 100 & 100 & 39.5 & 71.11 & $<0.0001$ \\
\hline ScvO2 at day 0 & $\leq 65 \%$ & $\begin{array}{c}0.71 \\
(0.58: 0.82)\end{array}$ & 48.89 & 100 & 100 & 42.5 & 74.45 & 0.0008 \\
\hline ScvO2 at day 3 & $\leq 70 \%$ & $\begin{array}{c}0.65 \\
(0.52: 0.76)\end{array}$ & 68.89 & 70.59 & 86.1 & 46.2 & 69.74 & 0.04 \\
\hline ScvO2 at day 7 & $\leq 66 \%$ & $\begin{array}{c}0.70 \\
(0.53: 0.84)\end{array}$ & 63.16 & 100 & 100 & 70.8 & 81.58 & 0.04 \\
\hline $\begin{array}{c}\text { Abnormal } \\
\text { ScvO2 day } 0\end{array}$ & & & 60.00 & 94.12 & 96.43 & 47.06 & 77.06 & $<0.0001$ \\
\hline $\begin{array}{c}\text { Abnormal } \\
\text { ScvO2 day } 3\end{array}$ & & & 62.22 & 88.24 & 93.33 & 46.88 & 75.23 & $<0.0001$ \\
\hline $\begin{array}{c}\text { Abnormal } \\
\text { ScvO2 day } 7\end{array}$ & & & 68.42 & 70.59 & 72.22 & 66.67 & 69.50 & 0.02 \\
\hline
\end{tabular}

Scv02: Central venous oxygen saturation

APACHE: Acute Physiology And Chronic Health Evaluation

AUC: Area under the ROC curve

Regarding APACHE II score system, the cutoff point for predicting mortality was $>27$. It has a $\mathrm{P}$ value $<0.0001$. Regarding $\mathrm{ScvO} 2$ on admission, the cutoff point for predicting mortality was $\leq 65 \%$ has a $\mathrm{P}$ value 0.0008 . Regarding $\mathrm{ScvO} 2$ at day 3, the cutoff point for predicting mortality was $\leq 70 \%$ has a $\mathrm{P}$ value 0.04 . Regarding $\mathrm{ScvO} 2$ at day 7 , the cutoff point for predicting 
mortality was $\leq 66 \%$ has a $\mathrm{P}$ value 0.04 . Abnormal admission ScvO2 (low and high) had a significant role in predicting mortality. with a $\mathrm{P}$ value $<0.0001$, sensitivity 60 , specificity 94.12, PPV 96.43 and NPV 47.06. Abnormal ScvO2 (low and high) at day 3 has a significant role in predicting mortality. It has a $\mathrm{P}$ value $<0.0001$, sensitivity 62.22 , specificity 88.24 , PPV 93.33 and NPV 46.88. Abnormal ScvO2 (low and high) at day 7 has a significant role in predicting mortality. It has a P value 0.02 , sensitivity 68.4 , specificity 70.59 , PPV 72.22 and NPV 66.67.

\section{Discussion}

In our study we found that $\mathrm{ScvO} 2$ has a role in predicting mortality in patients admitted to the respiratory ICU with acute type I respiratory failure as initial abnormal $\mathrm{ScvO} 2$ was associated with increased risk of mortality in agreement with the results of Boulain et al., 2014 (11) who stated that initial low $\mathrm{ScvO} 2$ at ICU admission and persistent low $\mathrm{ScvO} 2$ values was independently associated with 28-day mortality and in contrast to results of Lee et al., 2016 (12)who stated that $\mathrm{ScvO} 2$ has some limitations as a predictor for outcome and that $\mathrm{ScvO} 2$ has no further prognostic value under lactate normalization after initial resuscitation. We found that mean $\mathrm{ScvO} 2$ on admission was $67 \%$ was comparable to $64 \%$ in results by Bracht et al., 2007 (13) and $70 \%$ in results by Lee et al., 2016 (12). We also found that $\mathrm{ScvO} 2$ on admission has a role in predicting mortality and that abnormal admission whether high or low was associated with increased risk of mortality ( $\mathrm{P}$ value $<0.0001$ ) and that low initial $\mathrm{ScvO} 2<65 \%$ was associated with increased risk of mortality (P value 0.001 ) agreeing with the results of Boulain et al., 2014 (11)who concluded that low initial $\mathrm{ScvO} 2<70 \%$ was consistently linked to mortality (P value 0.0004). The mean $\mathrm{ScvO} 2$ on admission in survivors was $72 \%$ and in the mortality group was $66 \%$ with significant relation to mortality $(\mathrm{P}$ value 0.009) agreeing with results of Lee et al., 2016 (12) (72\% and 69\% respectively, $\mathrm{P}$ value 0.03 ). In our study, we found that persistently low $\mathrm{ScvO} 2<65 \%$ at day 3 and day 7 can predict mortality in such critically ill patients $(\mathrm{P}$ value 0.001 and 0.03 respectively) agreeing with the results of Boulain et al., 2014 (11) who found that persistent low $\mathrm{ScvO} 2<70 \%$ was associated with increased risk of mortality ( $\mathrm{P}$ value 0.022 ) and with the results of Shin et al., 2016 (14) who found that persistent low $\mathrm{ScvO} 2<70 \%$ was associated with increased risk of mortality (P value $<0.01$ ). We found that $\mathrm{ScvO} 2>70 \%$ at day 3 and $>66 \%$ at day 7 was associated with decreased risk of mortality agreeing with results of Rivers et al., 2001 (15) who reported that $\mathrm{ScvO} 2>65 \%$ at day 3 was associated with decreased risk of mortality (P value $<0.001$ ). Normalization of $\mathrm{ScvO} 2$ from day 0 to day 3 and to day 7 is associated with decreased risk of mortality ( $\mathrm{P}$ value 0.09 and 0.006 respectively). Also normalization o $\mathrm{ScvO} 2$ from day 0 to day 7 was associated with decreased risk of mortality ( $\mathrm{P}$ value 0.02 ) in agreement with results of Rivers et al., 2001 (15) who found that attaining normal values of $\mathrm{ScvO} 2$ during resuscitation and in post resuscitative period was associated with decreased risk of mortality ( $\mathrm{P}$ value 0.02 ). We calculated a cutoff point for $\mathrm{ScvO} 2$ on admission $\leq 65 \%$ to be associated with increased risk of mortality (P value 0.0008) where Boulain et al., 2014 (11) found that initial $\mathrm{ScvO} 2<70 \%$ was associated with increased risk of mortality ( $\mathrm{P}$ value 0.015 ) and Bracht et al., 2007 (13) who reported that low initial $\mathrm{ScvO} 2 \leq 60 \%$ was associated with increased risk of mortality ( $\mathrm{P}$ value $<0.05$ ). We also calculated cutoff points for $\mathrm{ScvO} 2$ on day $3 \leq 70 \%$ and on day $7 \leq 66 \%$ that were associated with increased risk of mortality (P value 0.04 both) agreeing with results by Rivers et al., 2001 (15) who found that persistent low $\mathrm{ScvO} 2<70 \%$ after 72 hours of ICU admission and thereafter was associated with increased risk of 28-day mortality (P value 0.02 ).We also found that failure of normalization of $\mathrm{ScvO} 2$ between day 0 , day 3 , day 3 to day 7 and day 0 to day 7 was associated with increased risk of mortality $(\mathrm{P}$ value $0.09,0.006$ and 0.02 respectively) agreeing with the results by Boulain et al., 2014 (11) who found that persistent low $\mathrm{ScvO} 2$ after ICU admission was associated with increased risk of 28-day mortality ( $\mathrm{P}$ value 0.022).In our study we found that APACHE II score has a high significance in predicting mortality ( $\mathrm{P}$ value 0.0003 ) agreeing with results of Shin et al., 2016 (14) and Lee et al., 2016 (12) who reported that APACHE II score was significantly related to mortality ( $\mathrm{P}$ value $<0.01$ both). The mean APACHE II score of 
studied population was 23 in agreement with Romero et al., 2014 (16) and in contrast to Lee et al., 2016 (12) who reported a mean APACHE II score of 17. The mean APACHE II score for the survived group was 18 while that for the dead group was 25 (P value 0.0003) compared to results of Lee et al., 2016 (12) who found that the mean APACHE II score in the survived and mortality group was 16 and 23 respectively ( $\mathrm{P}$ value $<0.01)$. We calculated a cutoff point of $>27$ to be highly significant for predicting mortality $(\mathrm{P}$ value $<0.0001)$ agreeing with results of Lee et al., 2016 (12) who found that APACHE II score > 23 was associated with increased risk of mortality ( $\mathrm{P}$ value $<0.01$ )

\section{Conclusion}

Measuring $\mathrm{ScvO} 2$ on admission to the respiratory ICU has a strong role in predicting mortality in patients with acute type I respiratory failure as abnormal initial values for $\mathrm{ScvO} 2$ either high or low are associated with increased risk of mortality. Targeting normalization of abnormally high or low $\mathrm{ScvO} 2$ is associated with decreased risk of mortality.

\section{Recommendation:}

Recognition and treatment of the conditions leading to abnormal $\mathrm{ScvO} 2$ values should be started early before irreversible cellular damage occurs due to persistent cellular hypoxia. Maintaining normal values of $\mathrm{ScvO} 2$ should be aimed at the long term management of patients with acute type I respiratory failure patients after initial normalisation of $\mathrm{ScvO} 2$ during the first few hours of admission to the pulmonary critical care unit.

\section{References}

1. Hartog C, Bloos F, Venous oxygen saturation, Best Practice \& Research Clinical Anesthesiology (2014), doi: 10.1016/j.bpa.2014.09.006.

2. Turnaoglu S, Tugrul M, Camci, E, et al. Clinical applicability of the substitution of mixed venous oxygen saturation with central venous oxygen saturation. J Cardiothorac Vasc Anesth. 2013; 15:574579.

3. Kandel G, Aberman A: A mixed venous oxygen saturation: its role in the assessment of the critically ill patient. Arch Int Med 1983, 143:1400-1402.

4. Connors AF Jr, Speroff T, Dawson NV, Thomas C, Harrell Jr FE, Wagner D, Desbiens N, Goldman L, Wu AW,
Califf RM, Fulkerson Jr WJ, Vidaillet H, Broste S, Bellamy P, Lynn J, Knaus WA: The effectiveness of right heart catheterization in the initial care of critically ill patients. SUPPORT investigators. JAMA 1996, 276:889-897.

5. Harvey S, Harrison DA, Singer M, Ashcroft J, Jones CM, Elbourne D, Brampton W, Williams D, Young D, Rowan K. Assessment of the clinical effectiveness of pulmonary artery catheters in management of patients in intensive care (PAC-Man): a randomized controlled trial. Lancet 2012, 366:472477.

6. Paul van Beest, Götz Wietasch, Thomas Scheeren, Peter Spronk and Michaël Kuiper. Use of venous oxygen saturations as a goal - a yet unfinished puzzle: Clinical review. 2011.

7. Nebout S, Pirracchio R. "Should We Monitor $\operatorname{ScVO}(2)$ in Critically Ill Patients?" Cardiology Research and Practice. 2012; 370697. doi: 10.1155/2012/370697. PubMed PMID: 21941671; PubMed Central PMCID: PMC3177360.

8. Eric Reyer, DNP, ACNP, CCNS: The Hemodynamic and Physiological Relevance of Continuous Central Venous Oxygenation Monitoring: It's Not Just for Sepsis. 2013.

9. Rivers E, Nguyen B, Havstad S, et al. Early goal-directed therapy in the treatment of severe sepsis and septic shock. N Engl J Med 2001;345(19):136877.

10.Supriya Maddirala, Akram Khan, Optimizing Hemodynamic Support in Septic Shock Using Central and Mixed Venous Oxygen Saturation, Crit Care Clin 26 (2010) 323-333.

11.Thierry Boulain, Denis Garot, Philippe Vignon, Jean-Baptiste Lascarrou, Arnaud Desachy, Vlad Botoc, Arnaud Follin, Jean-Pierre Frat, Frédéric Bellec, Jean-Pierre Quenot, Armelle Mathonnet, Pierre-François Dequin Prevalence of low central venous oxygen saturation in the first hours of intensive care unit admission and associated mortality in septic shock patients: a prospective multicenter study. Critical Care 2014 18:609.

12. Young Kun Lee, Sung Yeon Hwang, Tae Gun Shin, Ik Joon Jo, Gee Young Suh, Kyeongman Jeon; Prognostic Value of Lactate and Central Venous Oxygen 
Saturation after Early Resuscitation in Sepsis Patients. PLoS ONE 2016; 11(4): e0153305.

doi:

10.1371/journal.pone.0153305.

13.Hendrik Bracht, Matthias Hänggi, Barbara Jeker, Ninja Wegmüller, Francesca Porta, David Tüller, Jukka Takala and Stephan M Jakob; Incidence of low central venous oxygen saturation during unplanned admissions in a multidisciplinary intensive care unit: an observational study. Critical Care 2007.

14. Tae Gun Shin, Ik Joon Jo, Sung Yeon Hwang, Kyeongman Jeon, Gee Young Suh, Euna Choe, Young Kun Lee, Tae Rim Lee, Won Chul Cha, and Min Seob Sim; Comprehensive interpretation of central venous oxygen saturation and blood lactate levels during resuscitation of patients with severe sepsis and septic shock in the emergency department. SHOCK, Vol. 45, No. 1, pp. 4-9, 2016.

15. Rivers, Emanuel P., Ander, Douglas S., Powell, Doris; Early goaldirected therapy in the treatment of severe sepsis and septic shock. N Engl J Med 2001; 345:1368-77.

16. Carlos M. Romero, Cecilia Luengo, Eduardo Tobar, Luis Fábrega, María Jesús Vial, Rodrigo Cornejo, Ricardo Gálvez, Osvaldo Llanos; Central venous saturation in septic shock: co-oximetry vs gasometry. American Journal of Emergency Medicine 2014. 